\title{
The improvement of mathematics understanding ability on system of linear equation materials and students learning motivation using geogebra-based educational games
}

\author{
Ari Septian ${ }^{1 *}$, Erma Monariska ${ }^{1}$ \\ ${ }^{1}$ Universitas Suryakancana, Indonesia \\ $\underline{\text { ariseptian@unsur.ac.id }}$
}

Article Information

Submitted Sept 22, 2021

Revised Oct 06, 2021

Accepted Oct 16, 2021

Keywords

Educational Game;

GeoGebra

Mathematical Understanding

Ability;

Learning Motivation;

System of Linear Equations;

\begin{abstract}
The purpose of this research is to determine the improvement of students mathematical understanding ability on a system of linear equations using GeoGebra-based game education. This research use quasi-experimental that was conducted on two classes of the school in Indonesia. Class X MIPA 4 as experimental class and X MIPA 3 as control class. Based on the results the average score of $\mathrm{N}$-Gain value analysis, mathematical concept understanding ability in the experimental class is 0.55 , and the control class average score is 0.30 . Based on the calculation, the Asymp. Sig. ( 2 tailed) of 0.000 is obtained. Because the significance score is obtained less than 0.05 , thus it is rejected and is accepted. So, it can be concluded that the improvement of students' mathematical understanding ability using GeoGebra-based game education is better than the improvement through ordinary learning. The learning motivation of students using GeoGebra-based game education as a positive learning media, but there is no relationship between learning motivation and students' mathematical understanding using GeoGebra-Based Game Education.
\end{abstract}

\section{INTRODUCTION}

The importance of learning mathematics is mentioned by the National Council of Teachers of Mathematics (NCTM) that "The ability in mathematics will open the door to a productive future. All students must have the opportunity and support needed to learn mathematics ". Another important factor in mathematics learning is the importance of developing students' mathematical understanding abilities (NCTM, 2000; Suwarto \& Purnami, 2018). One way to develop students' mathematical understanding is that students must be active and practice a lot (Korenova, 2017; Sulistyowati, Budiyono, \& Slamet, 2017). Students in learning must do a lot of exercises, the more and more often and work hard in doing the exercises, the better the results in learning (Anggriani \& Septian, 2019; Gita Andriani \& Atmojo, 2013).

However, in reality, education in Indonesia has not shown satisfactory results based on the results of the PISA (Program for International Student Assessment) survey for Indonesia in 2018 which was announced by The Organization for Economic Co-operation and Development (Yuli Belfali, 2019). The assessment of the knowledge of students aged 14-15 years shows that Indonesia is still ranked below in the field of mathematics. Indonesia participated in PISA in early 2000 when it was ranked 39 out of 41 countries with a score of 367 . In 2015 Indonesia was ranked $626^{\text {th }}$ with an average of 386. While in 2018 Indonesia ranked 73 with an average of 379. When viewed from a comparison between 2015 and 2018, Indonesia experienced a decline.

The research results of Febrina in 2017, were taken from one of the results of the analysis of PISA questions regarding students' mathematical understanding abilities, namely the ability of students to solve PISA level 6 questions. There are 2 students who can finish correctly with

$\begin{array}{ll}\text { How to cite } & \text { Septian, A., \& Monariska, E. (2021). The improvement of mathematics understanding ability on system of linear } \\ \text { equation materials and students learning motivation using geogebra-based educational games. Al-Jabar: Jurnal } \\ \text { Pendidikan Matematika, 12(2), 371-384. } \\ \text { E-ISSN } \\ \text { Published by }\end{array}$


the correct answer presentation of $8.69 \%$. Both of these students understand the problems in the questions and concepts so that they can solve problems by modeling the problems contained in the questions (Bidasari, 2017).

In the opinion of Alan and Afriansyah in 2017 the current field conditions in general mathematics learning do not involve the activities of students, most students seem to follow well every explanation or information from the teacher, students very rarely ask questions so the teacher is absorbed in explaining what it has been conveyed (Alan \& Afriansyah, 2017). NCTM explains that students must learn mathematics with the ability to understand because the ability to understand is the ability to build new knowledge from experience and prior knowledge (NCTM, 2000).

The importance of improving students' mathematical understanding abilities, namely to instill basic mathematical concepts in linear equation systems to be understood as a whole, so that the concepts given are very important in improving other mathematical abilities such as representation, connection, and mathematical problem-solving abilities. This is also in line with the goal of education in Indonesia to improve all abilities in their respective fields. The ability to understand mathematics is a fundamental ability that must be possessed by every student because it is related to other material in mathematics itself.

In addition to mathematical understanding ability, another aspect that must be possessed by students is of course motivation to learn. According to Hamalik (Hendriawan \& Septian, 2019), motivation determines the level of success or failure of student learning activities. Learning without motivation is difficult to achieve success optimally (El-Adl \& Alkharusi, 2020; $\mathrm{Hu}, \mathrm{Wu}$, \& Shieh, 2016; Khan, Johnston, \& Ophoff, 2019). Therefore, motivation is one of the important points in learning (Effendi, 2018).

From these problems, it is obtained a way that can be done to achieve both aspects, namely the use of instructional media (Fatahillah, Puspitasari, \& Hussen, 2020). The learning style into three groups: visual learning groups that access learning through visual images, auditorial learning groups that access learning through listener imagery, and kinesthetic learning groups that access learning through movement, emotions, and physical (Wassahua, 2016). Therefore, at the educational stage, students will tend to be more interested in games that are easy to play and in which there are bright colors and animated images that attract attention (Kidi et al., 2017; Kirci \& Kahraman, 2015). In this stage, students will find it easier to remember a formula or way of working on a problem if it is found again in a form of writing that has attractive color features and a pleasant communicative form.

The use of media in the learning process can increase students' learning motivation so that students' attention to learning material can be increased (Hendriawan \& Septian, 2019; Ari Septian \& Komala, 2019). One of the most popular learning media in the world of education today is the game media (Alkhateeb \& Al-Duwairi, 2019; U. N. Pratama \& Haryanto, 2018; Yildiz, 2018). Students who learn mathematics using games are better than students who learn without using games (Aristizabal, Colorado, \& Gutierrez, 2016; Handriyantini, 2009; L. D. Pratama \& Setyaningrum, 2018). With the condition that the game does not reduce the effectiveness in learning mathematics. The media that will be used as a game in this research is the GeoGebra application (Cukierman et al., 2014; Ari Septian \& Komala, 2019). GeoGebra is a computer program to teach students the concepts of geometry and algebra (Hohenwarter, Hohenwarter, Kreis, \& Lavicza, 2008; Wulandari \& Raditya, 2017). 
The previous researches provide information that improving students' mathematical understanding requires more effort by using GeoGebra media (Kounlaxay, Shim, Kang, Kwak, \& Kim, 2021; Yildiz, 2018). Several researches related to the use of GeoGebra based on Game Education are still rarely carried out in research in schools. The previous researches still mostly only use GeoGebra as a medium without making it an interesting educational game. The previous researches still have not maximized GeoGebra as an Educational Game that improves students' mathematical understanding. The difference between this research and previous researches is that it has not focused on increasing mathematical understanding and using different materials. In addition, this research examines things that have not existed in previous researches, namely examining students' learning motivation and seeing the relationship between learning motivation and students' mathematical understanding abilities.

Thus, it is expected that the existence of GeoGebra-Based Game Education can improve students' mathematical understanding abilities and learning motivation. The objectives of this research are to find out the improvement of students' mathematical understanding abilities by using GeoGebra-Based Game Education is better than students who get ordinary learning; to determine students' learning motivation by using GeoGebra-Based Game Education; to determine the relationship between students' mathematical understanding and students' learning motivation in the application of GeoGebra-Based Game Education.

\section{METHODS}

This research method uses quasi-experimental, because not all variables can be controlled. This research involved two classes, namely the experimental class and the control class in which both classes were given different treatments. Where for the experimental class using cooperative learning models with game education while the control class using the usual learning model. Before the implementation of the treatment of both classes will be given a test in the form of a pretest to find out the situation before the given treatment. After that, the experimental class will be given treatment. Finally, the two classes will be given a posttest. The research design is as follows:

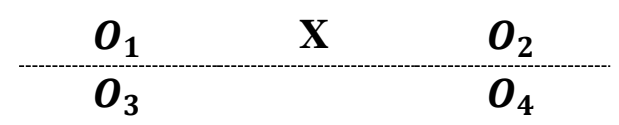

Information:

$\mathrm{O}_{1}$ : The experimental group before being given the treatment

$\mathrm{O}_{2}$ : $\quad$ Experimental group after being given the treatment

$\mathrm{O}_{3}$ : Control group being given before the treatment

$\mathrm{O}_{4}$ : Control group that is not given the treatment

$\mathrm{X} \quad$ : Treatment (use of GeoGebra Based-Games Education)

This research was conducted at MAN 1 Cianjur starting from February $14^{\text {th }}, 2020$ to March $14^{\text {th }}, 2020$. Subjects in this research were: class X MIPA 4 as an experimental class and class X MIPA 3 as a control class. The instrument in this research consisted of tests and non-tests. Data collection instruments are a series of questions used to measure the skills, knowledge, intelligence, abilities, or talents of an individual or group. The test in this research uses pretest and posttest mathematical understanding ability of students, while for non-tests using a closed 
questionnaire with a measurement scale used is a Likert scale, namely: SA (Strongly Agree), A (Agree), D (Disagree), and SD (Strongly Disagree) to measure students' learning motivation.

Before giving instruments to the research subjects, the instruments were first tested to determine the validity and reliability of each item. Researchers conducted instrument testing in class XI MIPA 4 at MAN 1 Cianjur with 30 respondents. The trial results that have been obtained are then analyzed and processed using SPSS 20 so that all items tested are valid and reliable so that the test instruments in this research are proper to use. Data analysis techniques used are normality test, homogeneity test, Mann-Whitney test, two-variable correlation test. A brief presentation of this research flowchart is presented in Figure 1.

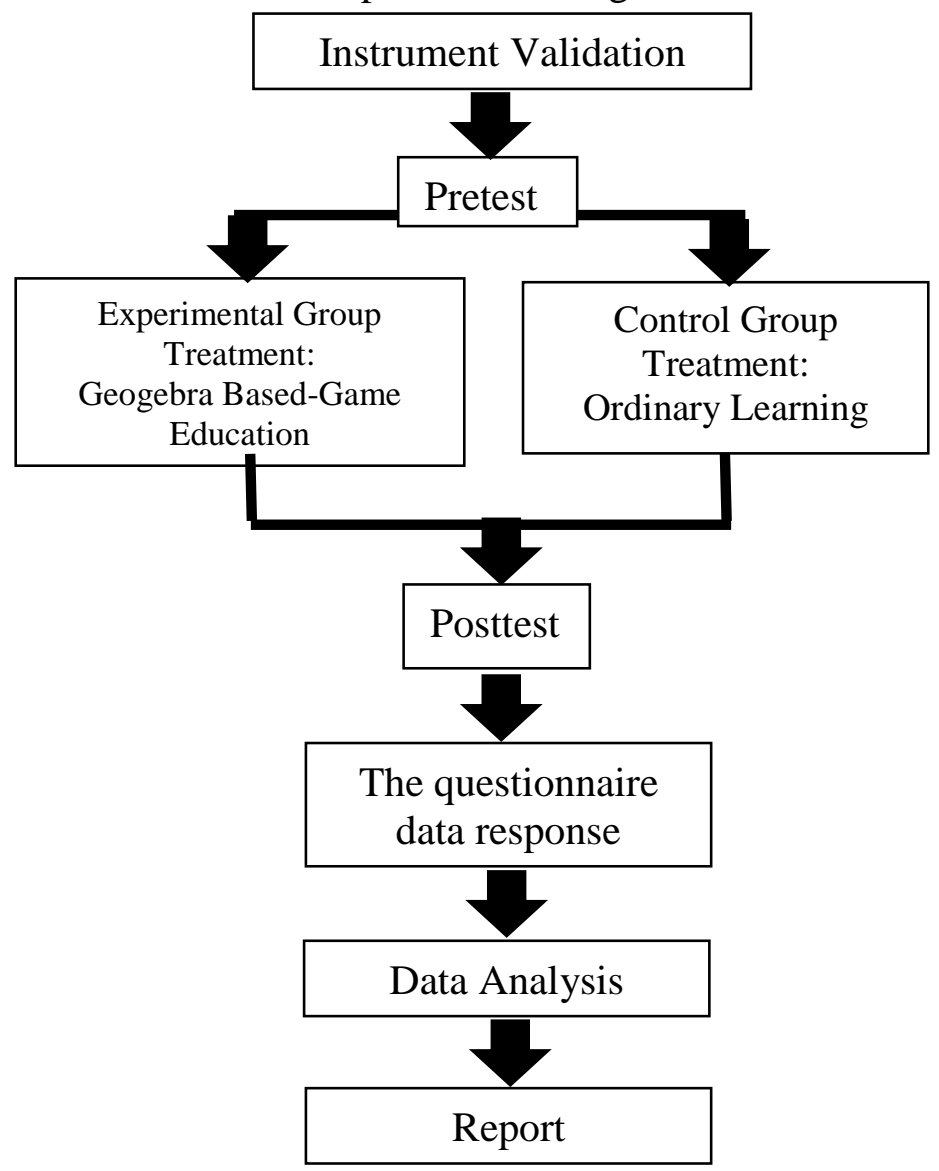

Figure 1. Research Flowchart

\section{RESULTS AND DISCUSSION}

\section{Initial Mathematical Understanding Ability}

The results obtained in the form of quantitative data, namely test scores in the form of pretest and posttest regarding the ability of mathematical understanding, and non-test in the form of a questionnaire scale results on students' learning motivation. The purpose is to give a pretest to find out whether the initial ability of mathematical understanding of the two classes is the same or not before being given the treatment. Following are the results of the descriptive statistical analysis of the pretest data of the experimental class and the control class: 
Table 1. Descriptive Statistics of Pretest Data

\begin{tabular}{lcccccc}
\hline Class & N & $\begin{array}{c}\text { Ideal } \\
\text { Score }\end{array}$ & Average & $\begin{array}{c}\text { Standard } \\
\text { Deviation }\end{array}$ & $\begin{array}{c}\text { Minimum } \\
\text { Score }\end{array}$ & $\begin{array}{c}\text { Maximum } \\
\text { Score }\end{array}$ \\
\hline Experiment & 30 & 20 & 9.07 & 2.24 & 6 & 15 \\
Control & 30 & 20 & 8.07 & 2.90 & 2 & 14 \\
\hline
\end{tabular}

Based on table 1, it can be seen that the average pretest score of the experimental class is 9.07, while for the control class an average of 8.07 is obtained. From the description of the data, it can be seen that the average score of the experimental class is greater than the average score of the control class with an average difference of 1 . However, to find out whether the initial ability of mathematical understanding is the same or not, then the pretest value of the experimental class and the control class must be tested with the following statistical tests:

Population Distribution Normality Test is conducted to determine whether the pretest obtained from the two classes is normally distributed or not. The following is the results of data processing with the test of normality from Shapiro-Wilk:

Table 2. Results of Normality Tests

\begin{tabular}{lcl}
\hline \multirow{2}{*}{\multicolumn{1}{c}{ Class }} & \multicolumn{2}{c}{ Shapiro-Wilk } \\
\cline { 2 - 3 } & Sig. & \multicolumn{1}{c}{ Conclusion } \\
\hline Experiment & 0.049 & Pretest data is not normally distributed. \\
Control & 0.455 & Pretest data is normally distributed. \\
\hline
\end{tabular}

Based on the results of the normality test of population distribution in table 2 , the significance value obtained for the experimental class was 0.049 and the control class was 0.455 . As for $\mathrm{H}_{0}$ : Pretest data is normally distributed. Because the significance value of the experimental class is less than 0.05 then $\mathrm{H}_{0}$ is rejected and the control class is more than 0.05 then $\mathrm{H}_{0}$ is accepted, so it can be concluded that the sample of the experimental class is not normally distributed and the control class is normally distributed. Because it appears that one of the two data do not originate from a normally distributed population, the data analysis was followed by a nonparametric statistical test, the Mann-Whitney test using SPSS 20.

The Mann-Whitney test was performed to see whether the students' initial mathematical understanding abilities were the same or not. The following is the results of Mann-Whitney data processing:

Table 3. Mann-Whitney Pretest Data Results

\begin{tabular}{cc} 
Asymp. Sig. (2-tailed) & Conclusion \\
\hline $\mathbf{0 . 1 5 5}$ & $H_{0}$ is accepted
\end{tabular}

Based on the Mann-Whitney test results in table 3, it is obtained that significance values for Asymp. Sig. (2-tailed) is 0.155 . As for $\mathrm{H}_{0}$ : Pretest data of the experimental class and the control class are the same. Because the significance value obtained is more than $0.05, \mathrm{H}_{0}$ is accepted. Thus, it can be concluded that the initial ability of mathematical understanding of students in the experimental class and the control class is the same.

\section{Improving Students' Mathematical Understanding Ability}

Gain index data analysis was performed to determine the average increase in the ability of mathematical understanding of experimental class and control class students after each class was given a different treatment. 
Table 4. Descriptive Statistics of Gain Index Data

\begin{tabular}{llccccc}
\hline \multicolumn{1}{c}{ Class } & N & $\begin{array}{c}\text { Ideal } \\
\text { Score }\end{array}$ & Average & $\begin{array}{c}\text { Standard } \\
\text { Deviation }\end{array}$ & $\begin{array}{c}\text { Minimum } \\
\text { Score }\end{array}$ & $\begin{array}{c}\text { Maximum } \\
\text { Score }\end{array}$ \\
\hline Experiment & 30 & 20 & 0.55 & 0.25 & -0.40 & 1.00 \\
Control & 30 & 20 & 0.30 & 0.24 & -0.11 & 0.89 \\
\hline
\end{tabular}

Based on table 4, it can be seen that the average gain index of the experimental class is 0.55 , while for the control class an average of 0.30 is obtained. The description shows that the average value of the experimental class gain index is greater than the average gain index of the control class. But to get more objective results and find out whether the average gain index is significant or not, the gain index data of the two classes must be tested with the following statistical tests:

Normality test is used to determine the results of the gain index obtained from both classes are normally distributed or not and determine the statistics that will be used next. Here are the results of data processing with the normality test from Shapiro-Wilk:

Table 5. Test Results for Gain Index Data Normality

\begin{tabular}{ccc}
\hline \multirow{2}{*}{ Class } & \multicolumn{2}{c}{ Shapiro-Wilk } \\
\cline { 2 - 3 } & Sig. & Conclusion \\
\hline Experiment & 0.001 & The gain index data is not normally distributed \\
Control & 0.271 & The gain index data is normally distributed \\
\hline
\end{tabular}

Based on the results of the normality test of population distribution in table 5 , the significance value obtained for the experimental class was 0.001 and the control class was 0.271. As for $\mathrm{H}_{0}$ : Posttest data is normally distributed. Because the significance value of the experimental class is less than 0.05 then $\mathrm{H}_{0}$ is rejected and the significance value of the control class is more than 0.05 then $\mathrm{H}_{0}$ is accepted, so it can be concluded that the sample of the experimental class is not normally distributed and the control class is normally distributed. Because it appears that one of the two data does not originate from a normally distributed population, the data analysis was continued with a nonparametric statistical test, namely the Mann-Whitney test using SPSS 20. The following results of Mann-Whitney data processing:

Table 6. Mann-Whitney Results Gain Index Data

\begin{tabular}{cc}
\hline Asymp. Sig. (2-tailed) & Conclusion \\
\hline $\mathbf{0 . 0 0 0}$ & $H_{0}$ is Rejected \\
\hline
\end{tabular}

Based on the Mann-Whitney test results in table 6, the Asymp value was obtained. Sig. (2tailed) of 0.000. As for $\mathrm{H}_{0}$ : Gain Index data of the experimental class and the control class are the same. Because the significance value obtained is less than 0.05 then $\mathrm{H}_{0}$ is rejected. So, it can be concluded that the improvement of students' mathematical understanding ability that uses GeoGebra-Based Game Education learning is better than the improvement of students' mathematical understanding ability with ordinary learning on the system of linear equations material.

The results of this research as stated in the previous section provides an illustration that learning game education can provide a better learning process to develop students' mathematical understanding abilities compared to ordinary learning. The game is something that is fun to do and something that is entertaining, the game allows the active participation of students to learn and can provide direct feedback (Aristizabal et al., 2016; Mohd, Shahbodin, Sedek, \& Samsudin, 2020; Rahayu, Putri, Zulkardi, \& Hartono, 2019). Basically, games were created as a means of 
entertainment only, but it would be better if games were created as a learning tool so that children can be more creative in thinking (Cukierman et al., 2014; L. D. Pratama \& Setyaningrum, 2018).

The use of media really supports students in facilitating understanding in learning. The teachers need to provide concrete (real) media or teaching aids with the daily environment of students according to the material (Korenova, 2017). In addition, learning with the GeoGebra application makes students more active, think creatively, and easily understand the concepts being studied (Kounlaxay et al., 2021; Poon \& Wong, 2017). GeoGebra software demonstrations, presentations, and experiments in class were achieved better than classes using traditional methods (Alkhateeb \& Al-Duwairi, 2019; Cruz, Bento, \& Lencastre, 2020; Hernández, PerdomoDíaz, \& Camacho-Machín, 2020).

So that GeoGebra-Based Game Education can be used as alternative learning to improve mathematical understanding ability and be able to apply them in everyday life (Ridha, Pramiarsih, \& Widjajani, 2020). In the end, it is expected that students will become more aware of the subject matter they are learning so that it has a positive impact on their mathematical understanding ability. The advantages of game education are to simplify the learning process, increase concentration, make the learning atmosphere relaxed and fun, and become a fun learning tool (Bigdeli \& Kaufman, 2017). The game has several advantages, namely: the game is something fun to do, something entertaining and interesting. The game allows the active participation of students to learn (Rahayu et al., 2019).

The obstacles in learning game education assisted by GeoGebra are timing, the time used is generally used up for preparations such as seating preparation, media preparation for students to answer, media preparation. In addition, another obstacle that is obtained is that there are students who cannot see clearly and get a seat in the back. To overcome these obstacles, teachers rearrange their seats, so that each student can learn comfortably and can see clearly the questions given. To overcome time constraints, teachers must be able to streamline time so that the available time is sufficient for the learning process. The learning method used in this research has the advantage of how students become interested and motivated in learning. GeoGebra helps students in visually assisting in drawing graphs, finding solutions, exploring linear equation system materials so that they can improve students' mathematical understanding. An increase in students' mathematical understanding ability because learning is very interesting and fun. Students do communicate, understanding concepts, and cooperation. GeoGebra provides a visual representation so as to clarify and facilitate student learning (Nanang Supriadi, 2015; Surgandini, Sampoerno, \& Noornia, 2019).

In the learning process, the teacher provides an important explanation of the material being studied. After that, students followed up on the teacher's instructions in solving problems related to a system of linear equations. Learning activities also affect the condition of students in improving their mathematical understanding. Existing research on how to improve mathematical understanding ability is still not optimal. In this learning, students are required to solve mathematical problems that must be visually displayed to facilitate solving these problems.

GeoGebra based-game education provides an alternative in accelerating the improvement of students' mathematical understanding abilities. According to the theory, it is also said that game education has a positive impact on the development of students' thinking. Students become happier, interested, and focused on what is learned in class.

This research still has shortcomings in terms of the implementation of learning. There are several limitations in this research, including the limited facilities and the lack of time in 
exploring students' understanding abilities. This limitation becomes a recommendation for other researchers in developing technology-based teaching materials.

\section{Learning Motivation of Students}

Table 7. Results of Student Learning Motivation Questionnaire

\begin{tabular}{|c|c|c|c|c|c|}
\hline \multirow{2}{*}{ No } & \multirow{2}{*}{ Indicator } & \multirow{2}{*}{$\begin{array}{l}\text { Statement } \\
\text { Type }\end{array}$} & \multicolumn{2}{|c|}{$\%$} & \multirow{2}{*}{ Average (\%) } \\
\hline & & & Agree & Disagreee & \\
\hline \multirow[t]{2}{*}{1} & \multirow[t]{2}{*}{ Diligently Facing Tasks } & + & 100 & 0 & \multirow[t]{2}{*}{98.35} \\
\hline & & - & 3.3 & 96.7 & \\
\hline \multirow[t]{2}{*}{2} & \multirow{2}{*}{$\begin{array}{l}\text { Resilient Facing Difficulties (Not } \\
\text { Quick Desperate) }\end{array}$} & + & 86.6 & 13.4 & \multirow[t]{2}{*}{84.95} \\
\hline & & - & 16.7 & 83.3 & \\
\hline \multirow[t]{2}{*}{3} & \multirow{2}{*}{$\begin{array}{l}\text { Not Get Bored Quickly on Routine } \\
\text { Tasks }\end{array}$} & + & 100 & 0 & \multirow[t]{2}{*}{93.3} \\
\hline & & - & 13.4 & 86.6 & \\
\hline \multirow[t]{2}{*}{4} & \multirow[t]{2}{*}{ Happier Working Independently } & + & 90 & 10 & \multirow[t]{2}{*}{93.35} \\
\hline & & - & 3.3 & 96.7 & \\
\hline \multirow[t]{2}{*}{5} & \multirow{2}{*}{ Happy to Find and Solve Problems } & + & 80 & 20 & \multirow[t]{2}{*}{85} \\
\hline & & - & 10 & 90 & \\
\hline \multicolumn{5}{|c|}{ Average Percentage of Total Answers } & 90.99 \\
\hline
\end{tabular}

Based on Table 7, the answer to the students' learning motivation questionnaire from each indicator shows a positive attitude, so it can be concluded that the learning motivation of students towards learning game education in mathematics learning is positive. This is indicated by the average percentage of the total positive answers of students by $90.99 \%$ and can be interpreted to be in the criteria of almost all students motivated in learning.

Student learning motivation becomes positive due to several things, namely learning motivation is formed from internal factors and external factors of the person himself (Khan et al., 2019). The internal factors that drive how learning is important, how learning is needed, and how learning is self-determined (Hu et al., 2016). Theoretically, self-motivation factors depend on high curiosity and desire to learn from oneself. In the case of the research conducted, most of the students have high learning motivation (Barnard et al., 2018). This high learning motivation is a positive impact on the learning carried out. Learning using GeoGebra based-game education encourages students to understand the material well (da Silva, Junior, Ribeiro, \& Mauro, 2020).

From the research that has been done, the researcher considers that motivation is an important aspect of learning. Motivation is a process that determines the level of activity, intensity, consistency, and general direction of human behavior (Sugito, Susilowati, Hartono, \& Supartono, 2017). In this research, intrinsic learning motivation is more desirable and produces a better understanding than extrinsic learning motivation (Barnard et al., 2018). Students who are intrinsically motivated to learn to participate in academic assignments because they enjoy understanding it (Palomares-Ruiz, Cebrián, López-Parra, \& García-Toledano, 2020).

They feel that learning is important and they engage in learning activities solely for the joy of personal enjoyment of learning. Meanwhile, students who are extrinsically motivated to learn are involved in academic tasks to gain rewards or avoid punishment. The impact of using assessments on learning motivation and mathematical understanding is dichotomous, i.e. profitable or not harmful (Machromah, Purnomo, \& Sari, 2019). In addition, giving a grade that has a very positive impact on students' learning motivation, on the other hand, giving a grade weakens the learning motivation of other students. Because students who feel capable of being motivated to learn are likely to be successful and get praise, but not so students who are less 
capable may prefer to avoid failure by evaluating the assessment process (Eccles \& Wigfield, 2002).

In addition, the motivation from the teacher given every day has a good impact on students in learning. The learning carried out makes students not bored, students become interested, so that in the end the learning motivation is high or positive. Student learning motivation becomes good because the learning that is carried out gives attraction, fun, and is active (Kirci \& Kahraman, 2015). Learning with GeoGebra-Based Game Education combines the way games and technology applications help visually (A Septian, Darhim, \& Prabawanto, 2020). GeoGebra makes it easy for students to understand and work on problems (Saha, Ayub, \& Tarmizi, 2010).

This result is also in line with previous research which says that learning using technology will increase students' learning motivation. The results of previous researches also say that many students become happy and active in learning if they apply technology-based learning (Ari Septian, Sugiarni, \& Monariska, 2020; Suryawan \& Permana, 2020). Several researches also support that using GeoGebra as an educational game can encourage students to learn to be more interactive (A. Septian, Darhim, \& Prabawanto, 2020). This argument provides reinforcement that students will have high learning motivation if the learning is done by combining games and technology with GeoGebra.

\section{Correlation of Mathematical Understanding with Students' Learning Motivation}

The data used to analyze the relationship between mathematical understanding and learning motivation using the results of the posttest and the results of the questionnaire from the experimental class that has been obtained, which aims to find out whether there is a relationship or not between mathematical understanding with student motivation to learn. Here are the results of the Correlation Test analysis:

Table 8. Correlation Results Between Posttest Data and Questionnaire Learning Motivation

\begin{tabular}{lllr}
\hline & & X & \multicolumn{1}{c}{ Y } \\
\hline $\mathbf{X}$ & Pearson Correlation & 1 & 0.242 \\
\cline { 2 - 4 } & Sig. (2-tailed) & & 0.198 \\
\cline { 2 - 4 } & $\mathrm{N}$ & 30 & 30 \\
\hline
\end{tabular}

In this research, the dependent variable is the $\mathrm{Y}$ variable, namely the ability of mathematical understanding and the independent variable is the $\mathrm{X}$ variable, which is learning motivation. Based on the results of the correlation test in Table 8, obtained significance values for Sig. (2-tailed) the second relationship is 0.198 . Because the significance value obtained is more than 0.05 then $\mathrm{H}_{0}$ is rejected. Thus, it can be concluded that there is no significant relationship between mathematical understanding with students' learning motivation. Mathematical understanding ability and motivation to learn in this research do not have a significant relationship. This is caused by the students' prerequisite skills that were previously obtained (Monariska, 2017; Ari Septian, 2013). Although the motivation to learn is high, the ability of personal intelligence of each student has been formed (Bush \& Karp, 2013; Earhart, 1982).

Several factors of students have been motivated to learn in learning but do not improve their mathematical understanding, namely: forgetting and boredom. Several factors cause forgetting, as follows: a conflict disorder between the material that is in a person's memory system, the pressure on existing material, either intentionally or unintentionally, it could be because the information received is unpleasant so that it is intentionally forgotten or new 
information that has been received. Enter suppressing existing information because it has never been used, changes in the environmental situation between study time and recall time, the subject matter has never been studied or memorized. Several things cause learning saturation, a certain time span that is used to study but does not bring results usually because the brain cannot work, as usual, this is due to fatigue. A person's fatigue can be categorized into three types, namely, sensory fatigue, physical fatigue, and mental fatigue. So that it can cause students to not be able to concentrate on learning (Palomares-Ruiz et al., 2020).

This can be exemplified by students who are already motivated in learning mathematics so that they follow any given material, but when given the same problem with numbers or different problem situations it can make some students unable to do it or the results obtained are not as expected. This shows that there is no relationship between mathematical understanding and students' learning motivation.

\section{CONCLUSIONS}

Based on the results of data analysis and discussion of the results of the research described in the previous chapter, it is concluded that the improvement of the mathematical understanding ability of students who use GeoGebra-Based Game Education is better than students who get ordinary learning. Learning motivation of students towards GeoGebra-assisted mathematics education games as a positive learning media but there is no relationship of learning motivation with students' mathematical understanding in the application of GeoGebra-Based Game Education.

Based on the conclusions and results of the research, the researchers put forward some suggestions as follows: by applying game education to mathematics learning can be alternative learning that is applied to improve students' understanding abilities and learning motivation. GeoGebra-Based Game Education should be a choice of learning media that can be used by teachers in schools and the need for further researches by applying game education to various other more interesting media so that students are more motivated to learn mathematics with the help of learning media.

\section{AUTHOR CONTRIBUTIONS STATEMENT}

The US is the lead researcher in this study. He compiled an instrument of mathematical understanding on the material of linear equations. Then, EM helped in compiling a learning motivation questionnaire and took the data.

\section{REFERENCES}

Alan, U. F., \& Afriansyah, E. A. (2017). Kemampuan pemahaman matematis siswa melalui model pembelajaran auditory intellectualy repetition dan problem based learning. Jurnal Pendidikan Matematika, 11(1), 67-78. https://doi.org/10.22342/jpm.11.1.3890.67-78

Alkhateeb, M. A., \& Al-Duwairi, A. M. (2019). The effect of using mobile applications (geogebra and sketchpad) on the students' achievement. International Electronic Journal of Mathematics Education, 14(3), 523-533. https://doi.org/10.29333/iejme/5754

Anggriani, A., \& Septian, A. (2019). Peningkatan kemampuan komunikasi matematis dan kebiasaan berpikir siswa melalui model pembelajaran IMPROVE. IndoMath: Indonesia Mathematics Education, 2(2), 105-116. https://doi.org/10.30738/indomath.v2i2.4550 
Aristizabal, Z. J. H., Colorado, T. H., \& Gutierrez, Z. H. (2016). Game as didactic strategy to develop numerical thought in the four basic operations. Sophia-Educacion, 12(1), 117-125.

Barnard, L., Lan, W. Y., Crooks, S. M., Alexiou, A., Paraskeva, F., Bempechat, J., ... Champakaew, W. (2018). Educational psychology in practice: Theory, research and practice in educational psychology the impact of different teaching methods on students ' arithmetic and self - regulated learning skills. Learning and Instruction, 7(2), 37-41.

Bidasari, F. (2017). Pengembangan soal matematika model PISA pada konten quantity untuk mengukur kemampuan pemecahan masalah matematika siswa sekolah menengah pertama. Jurnal Gantang, 2(1), 63-77. https://doi.org/10.31629/jg.v2i1.59

Bigdeli, S., \& Kaufman, D. (2017). Digital games in health professions education: Advantages, disadvantages, and game engagement factors. Medical Journal of the Islamic Republic of Iran, 31(1), 780-785. https://doi.org/10.14196/mjiri.31.117

Bush, S. B., \& Karp, K. S. (2013). Prerequisite algebra skills and associated misconceptions of middle grade students: A review. Journal of Mathematical Behavior, 32(3), 613-632. https://doi.org/10.1016/j.jmathb.2013.07.002

Cruz, S., Bento, M., \& Lencastre, J. A. (2020). Geogebra book: Preliminary research with primary school students. Proceedings of the 17th International Conference on Cognition and Exploratory Learning in the Digital Age (CELDA 2020). https://doi.org/10.33965/celda2020_202014L035

Cukierman, U., Arnal, P., Cerasulo, P., Esperon, G., Fuertes, B., Aguero, M., ... Badaro, S. (2014). Playing with maths: Geogebra application for meaningful education. 2014 International Conference on Interactive Collaborative Learning (ICL), 243-248. https://doi.org/10.1109/ICL.2014.7017777

da Silva, J. B., Junior, F. P., Ribeiro, R. C., \& Mauro, R. C. (2020). Mathematical mission : A ludical and motivate educational game. 2020 15th Iberian Conference on Information Systems and Technologies (CISTI), 1-5. https://doi.org/10.23919/CISTI49556.2020.9140985

Earhart, E. M. (1982). Building prerequisite learning skills for reading and mathematics. Advances in Early Education \& Day Care, 2, 159-184.

Eccles, J. S., \& Wigfield, A. (2002). Motivational beliefs, values, and goals. Annual Review of Psychology, 53(1), 109-132. https://doi.org/10.1146/annurev.psych.53.100901.135153

Effendi, K. N. S. (2018). Penerapan pembelajaran advance organizer dalam peningkatan kemampuan pemahaman matematis dan motivasi belajar siswa SMK. Prima: Jurnal Pendidikan Matematika, 2(1), 33-48. https://doi.org/10.31000/prima.v2i1.419

El-Adl, A., \& Alkharusi, H. (2020). Relationships between self-regulated learning strategies, learning motivation and mathematics achievement. Cypriot Journal of Educational Sciences, 15(1), 104-111. https://doi.org/10.18844/cjes.v15i1.4461

Fatahillah, A., Puspitasari, I. D., \& Hussen, S. (2020). The development of Schoology web-based learning media with geogebra to improve the ICT literacy on quadratic functions. Journal of Research and Advances in Mathematics Education, 5(3), 304-316. https://doi.org/10.23917/jramathedu.v5i3.10692

Gita Andriani, D., \& Atmojo, T. K. (2013). Eksperimentasi model pembelajaran kooperatif tipe 
jigsaw ii dan think pair share ditinjau dari kecerdasan emosional siswa SMP se-kota kediri tahun pelajaran 2012/2013. Jurnal Elektronik Pembelajaran Matematika, 1(7), 651-660.

Handriyantini, E. (2009). Permainan edukatif berbasis (educational games) berbasis komputer untuk siswa sekolah dasar. Konferensi Dan Temu Nasional Teknologi Informasi Dan Komunikasi Untuk Indonesia, $130 . \quad$ Retrieved from file:///C:/Users/User/Downloads/7_131_Eva.pdf

Hendriawan, M. A., \& Septian, A. (2019). Pengembangan jimath sebagai multimedia pembelajaran matematika berbasis android untuk siswa sekolah menengah atas. IndoMath: Indonesia Mathematics Education, 2(1), 45-52.

Hernández, A., Perdomo-Díaz, J., \& Camacho-Machín, M. (2020). Mathematical understanding in problem solving with GeoGebra: A case study in initial teacher education. International Journal of Mathematical Education in Science and Technology, 51(2), 208-223. https://doi.org/10.1080/0020739X.2019.1587022

Hohenwarter, M., Hohenwarter, J., Kreis, Y., \& Lavicza, Z. (2008). Teaching and calculus with free dynamic mathematics software GeoGebra. 11th International Congress on Mathematical Education.

Hu, R., Wu, Y. Y., \& Shieh, C. J. (2016). Effects of virtual reality integrated creative thinking instruction on students' creative thinking abilities. Eurasia Journal of Mathematics, Science and Technology Education, 12(3), 477-486. https://doi.org/10.12973/eurasia.2016.1226a

Khan, T., Johnston, K., \& Ophoff, J. (2019). The impact of an augmented reality application on learning motivation of students. Advances in Human-Computer Interaction, 2019, 1-14. https://doi.org/10.1155/2019/7208494

Kidi, N., Kanigoro, B., Salman, A. G., Prasetio, Y. L., Lokaadinugroho, I., \& Sukmandhani, A. A. (2017). Android based indonesian information culture education game. Procedia Computer Science, 116, 99-106. https://doi.org/10.1016/j.procs.2017.10.015

Kirci, P., \& Kahraman, M. O. (2015). Game based education with android mobile devices. In 2015 6th international conference on modeling, simulation, and applied optimization (ICMSAO) (pp. 1-4). IEEE.

Korenova, L. (2017). GeoGebra in teaching of primary school mathematics. International Journal for Technology in Mathematics Education, 24(3), 155-160. https://doi.org/10.1564/tme_v24.3.08

Kounlaxay, K., Shim, Y., Kang, S. J., Kwak, H. Y., \& Kim, S. K. (2021). Learning media on mathematical education based on augmented reality. KSII Transactions on Internet and Information Systems, 15(3), 1015-1029. https://doi.org/10.3837/tiis.2021.03.011

Machromah, I. U., Purnomo, M. E. R., \& Sari, C. K. (2019). Learning calculus with geogebra at college. Journal of Physics: Conference Series, 1180(1). https://doi.org/10.1088/17426596/1180/1/012008

Mohd, C. K. N. C. K., Shahbodin, F., Sedek, M., \& Samsudin, M. (2020). Game based learning for autism in learning mathematics. International Journal of Advanced Science and Technology, 29(5), 4684-4691.

Monariska, E. (2017). Penerapan metode mind mapping untuk meningkatkan kemampuan pemahaman konsep matematis mahasiswa pada mata kuliah kalkulus I. PRISMA, 6(1), 17- 
31. https://doi.org/10.35194/jp.v6i1.25

Nanang Supriadi. (2015). Pembelajaran geometri berbasis geogebra sebagai upaya meningkatkan kemampuan komunikasi matematis siswa madrasah tsanawiyah (MTs). Al-Jabar: Jurnal Pendidikan Matematika, 6(2), 1-14.

NCTM. (2000). Principles and standards for school mathematics. In School Science and Mathematics (Vol. 47). Retrieved from www.nctm.org

Palomares-Ruiz, A., Cebrián, A., López-Parra, E., \& García-Toledano, E. (2020). Influence of ICTs on math teaching-learning processes and their connection to the digital gender gap. Sustainability (Switzerland), 12(16), 6692. https://doi.org/10.3390/su12166692

Poon, K. K., \& Wong, K. L. (2017). Pre-constructed dynamic geometry materials in the classroom - how do they facilitate the learning of 'similar triangles'? International Journal of Mathematical Education in Science and Technology, 48(5), 735-755. https://doi.org/10.1080/0020739X.2016.1264636

Pratama, L. D., \& Setyaningrum, W. (2018). Game-based learning: The effects on student cognitive and affective aspects. Journal of Physics: Conference Series, 1097(1). https://doi.org/10.1088/1742-6596/1097/1/012123

Pratama, U. N., \& Haryanto, H. (2018). Pengembangan game edukasi berbasis android tentang domain teknologi pendidikan. Jurnal Inovasi Teknologi Pendidikan, 4(2), 167-184. https://doi.org/10.21831/jitp.v4i2.12827

Rahayu, C., Putri, R., Zulkardi, \& Hartono, Y. (2019). Using mathematics education game based ICT: Why children like to play game? Journal of Physics: Conference Series, 1315, 012062. https://doi.org/10.1088/1742-6596/1315/1/012062

Ridha, M. R., Pramiarsih, E. E., \& Widjajani. (2020). The use of geogebra software in learning geometry transformation to improve students' mathematical understanding ability. Journal of Physics: Conference Series, 1477, 042048. https://doi.org/10.1088/17426596/1477/4/042048

Saha, R. A., Ayub, A. F. M., \& Tarmizi, R. A. (2010). The effects of GeoGebra on mathematics achievement: Enlightening coordinate geometry learning. Procedia-Social and Behavioral Sciences, 8, 686-693.. https://doi.org/10.1016/j.sbspro.2010.12.095

Septian, A., Darhim, \& Prabawanto, S. (2020). Mathematical representation ability through geogebra-assisted project-based learning models. Journal of Physics: Conference Series. https://doi.org/10.1088/1742-6596/1657/1/012019

Septian, A, Darhim, \& Prabawanto, S. (2020). Geogebra in integral areas to improve mathematical representation ability. Journal of Physics: Conference Series, 1613, 012035. https://doi.org/10.1088/1742-6596/1613/1/012035

Septian, Ari. (2013). Pengaruh kemampuan prasyarat terhadap kemampuan penalaran matematis mahasiswa dalam matakuliah analisis real. Atikan, 4(2), 179-188.

Septian, Ari, \& Komala, E. (2019). Kemampuan koneksi matematik dan motivasi belajar siswa dengan menggunakan model problem-based learning (PBL) berbantuan geogebra di SMP. PRISMA, 8(1), 1-13. https://doi.org/10.35194/jp.v8i1.438

Septian, Ari, Sugiarni, R., \& Monariska, E. (2020). The application of android-based geogebra 
on quadratic equations material toward mathematical creative thinking ability. Al-Jabar: Jurnal Pendidikan Matematika, 11(2), 261-272. https://doi.org/10.24042/ajpm.v11i2.6686

Sugito, S., Susilowati, S. M. E., Hartono, H., \& Supartono, S. (2017). The learning syntax through edmodo in the beginners class. International Journal of Evaluation and Research in Education (IJERE), 6(4), 299-305. https://doi.org/10.11591/ijere.v6i4.10773

Sulistyowati, F., Budiyono, B., \& Slamet, I. (2017). Problem solving reasoning and problem based instruction in geometry learning. Journal of Physics: Conference Series, 895(1). https://doi.org/10.1088/1742-6596/895/1/012045

Surgandini, A., Sampoerno, P. D., \& Noornia, A. (2019). Pengembangan pembelajaran dengan pendekatan pmri berbantuan geogebra untuk membangun pemahaman konsep transformasi geometri. Prima: Jurnal Pendidikan Matematika, 3(2), 85-102. https://doi.org/10.31000/prima.v3i2.932

Suryawan, I. P. P., \& Permana, D. (2020). Media pembelajaran online berbasis geogebra sebagai upaya meningkatkan pemahaman konsep matematika. Prisma, 9(1), 108-117. https://doi.org/10.35194/jp.v9i1.929

Suwarto, S., \& Purnami, A. S. (2018). Upaya meningkatkan pemahaman konsep matematika melalui hypothetical learning trajectory pada materi vektor. IndoMath: Indonesia Mathematics Education, 1(2), 69-76. https://doi.org/10.30738/indomath.v1i2.2614

Wassahua, S. (2016). Analisis gaya belajar siswa terhadap hasil belajar matematika pada materi himpunan siswa kelas VII SMP negeri karang jaya kecamatan namlea kabupaten buru. Jurnal Matematika dan Pembelajarannya, 2(1), 105-126. https://doi.org/http://dx.doi.org/10.33477/mp.v4i1.310

Wulandari, K. N., \& Raditya, A. (2017). Pengembangan lembar kerja siswa pada materi geometri transformasi menggunakan geogebra. Prima: Jurnal Pendidikan Matematika, 1(1), 83-90. https://doi.org/10.31000/prima.v1i1.257

Yildiz, H. (2018). The development process of a mathematic teacher's technological pedagogical content knowledge. European Journal of Educational Research, 7(1), 9-29. https://doi.org/10.12973/eu-jer.7.1.9

Yuli Belfali. (2019). Programme for international student assessment (PISA) 2018 result Indonesia. In OECD 2019. https://doi.org/10.1007/978-94-6209-497-0_69 